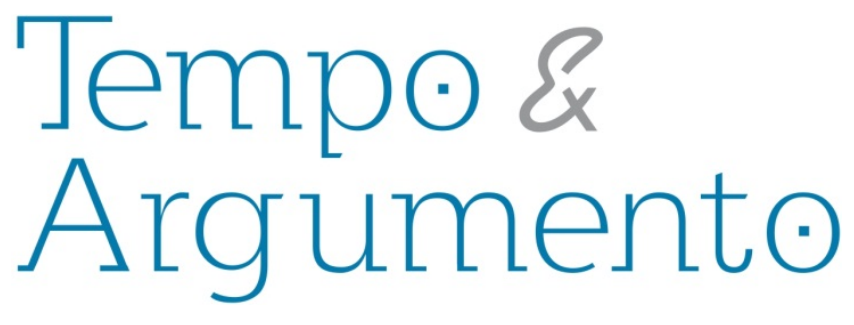

\title{
De Paris a Buenos Aires: ideias e intelectuais no Le Monde Diplomatique ${ }^{1}$
}

\begin{abstract}
Resumo
Este artigo pretende expor as relações entre os intelectuais e jornalistas imbricados nas edições latino-americanas e a edição francesa do periódico Le Monde Diplomatique. Fundado em maio de 1954, em Paris, Le Monde Diplomatique é considerado um fenômeno único na imprensa mundial devido à consolidação de suas edições internacionais. Ao longo de sua trajetória, a linha de Le Monde Diplomatique ficou marcada por posicionamentos anti-imperialistas e antineoliberais. Ancorado na história dos intelectuais e na história do tempo presente, este artigo aborda as relações entre intelectuais franceses e argentinos na consolidação de uma experiência singular da imprensa.
\end{abstract}

Palavras-chave: Le Monde Diplomatique; Imprensa; Intelectuais.

\author{
Juliana Sayuri Ogassawara \\ Jornalista, mestre e doutoranda do programa \\ de História Social na Faculdade de Filosofia, \\ Letras e Ciências Humanas da Universidade de \\ São Paulo (FFLCH-USP). Tem experiência nas \\ áreas de Jornalismo e História, com ênfase em \\ História Contemporânea, História dos \\ Intelectuais e História do Tempo Presente. \\ Brasil \\ julianasayuri.o@gmail.com
}

\section{Para citar este artigo:}

SAYURI, Juliana. De Paris a Buenos Aires: ideias e intelectuais no Le Monde Diplomatique. Revista Tempo e Argumento, Florianópolis, v. 7, n. 16, p. 230 - 265. set./dez. 2015.

\section{DOI: $10.5965 / 2175180307162015230$}

http://dx.doi.org/10.5965/2175180307162015230

\footnotetext{
1 este artigo corresponde a um segmento da tese de doutorado desenvolvida na Faculdade de Filosofia, Letras e Ciências Humanas da Universidade de São Paulo (FFLCH-USP), com apoio da Coordenação de Aperfeiçoamento de Pessoal de Nível Superior (CAPES) e orientação do Prof. Dr. Francisco Carlos Palomanes Martinho. A autora também realizou temporada de doutorado "sanduíche" na École des Hautes Études en Sciences Sociales, sob orientação do Prof. Dr. Michael Löwy, com apoio da Coordenação de Aperfeiçoamento de Pessoal de Nível Superior (CAPES) e do Santander.
} 


\title{
From Paris to Buenos Aires: ideas and intellectuals in Le Monde Diplomatique
}

\begin{abstract}
This article aims to analyze the role of intellectuals and journalists inside the Latin American and French editions of the international magazine Le Monde Diplomatique. Founded in May 1954, in Paris, Le Monde Diplomatique is considered a unique phenomenon in the international press due to the consolidation of its international editions. Through its history, Le Monde Diplomatique's editorial line was marked by positions against imperialism and neoliberalism. Anchored in history of intellectuals and history of present time, this article analyzes the relations between French and Argentinian intellectuals in the process of consolidation of an exclusive experience of the press.
\end{abstract}

Keywords: Le Monde Diplomatique; Press;

Intellectuals.

\section{Introdução}

Le Monde Diplomatique é uma história feita de muitas histórias. Idealizado pelo jornalista francês Hubert Beuve-Méry na Paris cosmopolita e diplomática da década de 1950, o magazine nasceu sob o signo do diário Le Monde. Intitulada inicialmente Le Monde Diplomatique: Journal des Cercles Consulaires et Diplomatiques, a gazeta se destinava ao universo das embaixadas diplomáticas e da elite econômica internacional, contando apenas oito páginas, periodicidade mensal e tiragem de até 5 mil exemplares. Na década de 1970, sob a direção do jornalista francês Claude Julien, o periódico conquistou independência editorial. Viria depois a independência econômica (em relação ao pai, Le Monde) e, na década de 1990, dirigida pelo sociólogo espanhol Ignacio Ramonet, a revista consolidou diretrizes declaradamente anti-imperialistas e antineoliberais e, surfando na 
onda do movimento altermundialista ${ }^{2}$, angariou leitores, jornalistas e intelectuais mundo afora, tornando-se um prestigiado periódico francês de 40 páginas com mais de 65 edições internacionais; nos melhores tempos, somando 2,4 milhões de exemplares no mundo todo, um fenômeno único na imprensa internacional. ${ }^{3}$

Este breve primeiro parágrafo já descortina diversas possibilidades de análise, envoltas num efeito matrioska: a cada gaveta de histórias destrancada, outras sete se abrem. Nestas breves páginas, focarei apenas a discussão sobre o papel dos intelectuais de Le Monde Diplomatique nas relações envolvidas entre França e América Latina, sobretudo simbolizada pela versão editada na Argentina, considerada a "filial" latinoamericana mais consolidada, epicentro para outras edições, outrora reunidas como Edición Cono Sur. ${ }^{4}$

À esquerda no espectro político, Le Monde Diplomatique mira suas críticas sobretudo ao imperialismo e ao capitalismo neoliberal. Diante das ruínas ideológicas do muro de Berlim e das ilusões perdidas na derrocada da União Soviética, é interessante investigar como tais intelectuais passaram a olhar as experiências da esquerda na

${ }^{2} \mathrm{O}$ movimento altermundialista se contrapõe ao capitalismo neoliberal, consolidando-se nas manifestações durante as reuniões internacionais das principais instituições financeiras, como nos protestos de Seattle em novembro de 1999. Trata-se de um movimento contra a globalização marcadamente neoliberal, tendo como auge a realização do primeiro Fórum Social Mundial em Porto Alegre, em janeiro de 2001. Ancorada no lema "outro mundo é possível", a expressão "altermundialismo" (do francês altermondialisme) foi idealizada a partir do movimento ATTAC, vinculado ao Le Monde Diplomatique francês.

3 Le Monde Diplomatique foi difundido na América Latina, na Ásia, na Europa e no Oriente Médio em diferentes momentos ao longo de sua trajetória. Além do francês, do inglês e do espanhol, foi traduzido para idiomas mais "distantes", como curdo sorâni, curdo kurmandji, esperanto, farsi e finlandês, entre outros. É difícil precisar o número de edições internacionais, pois a rede é muito fluida e às vezes frágil, assim muitas versões são repentinamente encerradas. Em novembro de 2006, o periódico atingiu a marca de 65 edições internacionais, em 25 idiomas além do francês. Em fevereiro de 2013, eram 47 edições internacionais, em 28 idiomas, entre versões impressas e estritamente eletrônicas.

4 Inicialmente voltada para Argentina, Chile e Uruguai, noutros momentos a edição foi distribuída na Bolívia, na Colômbia, no Peru, no México e na Venezuela. Além da estrutura administrativa mais consolidada desde 1999, a edição argentina de Le Monde Diplomatique é responsável por traduzir os artigos franceses para o espanhol, disponibilizando-os para as outras edições latino-americanas. Atualmente, diz o site oficial francês, há edições presentes na Bolívia (editada pela Archipielago Ediciones, com 5 mil exemplares), no Chile (Editorial Aún Creemos en los Sueños, com 10 mil exemplares), na Colômbia (Colombia Tebeo, com 10 mil exemplares) e na Venezuela (Productiones del Waraima, com 5 mil exemplares). Atualmente na casa dos 30 mil exemplares impressos, a edição argentina também é distribuída nas principais cidades do Uruguai. No Brasil, a versão impressa Le Monde Diplomatique Brasil estreou em agosto de 2007 (Instituto Pólis, com 40 mil exemplares), atualmente dirigida pelo sociólogo Silvio Caccia Bava, mas a edição eletrônica foi ao ar em dezembro de 1999, por iniciativa do jornalista Antonio Martins. 
capitalismo neoliberal?

Ao focar nas relações entre França e Argentina, a investigação focou continuidades e rupturas das diretrizes editoriais (e políticas) herdadas da matriz europeia na edição argentina. Ao mesmo tempo, destacou o possível impacto da realidade política latino-americana na perspectiva francesa. Mirando tais alvos, é preciso traçar linhas paralelas entre dois horizontes históricos neste estudo. Por um lado, é preciso jogar luz sobre os jornalistas argentinos, admiradores da intelectualidade francesa simbolizada por Le Monde Diplomatique, uma revista francesa "importada" para a América Latina. ${ }^{5}$ Por outro, explorar o interesse desses intelectuais franceses sobre a temática terceiro-mundista, principalmente latino-americana, entre fins do século XX e início do século XXI. Nessa perspectiva transatlântica, transnacional ${ }^{6}$, a análise de Le

${ }^{5}$ Le Monde Diplomatique não foi a primeira publicação francesa "importada" para a Argentina, isto é, a marcar diálogos entre França e América Latina. Ao longo da história, diversas revistas francesas inspiraram versões, traduções e edições nos países latino-americanos. A historiadora Patricia Funes destaca, por exemplo, a Clarté! de Henri Barbusse (1873-1935), que se desdobrou nas Claridades que inauguraram uma nova relação entre política e intelectuais na década de 1920: Claridad em Buenos Aires (1926-1941), Clarté! no Rio (1921-1922), em Santiago (1920-1924) e em Lima (1923-1924) (FUNES, 2006, p. 32). Outros exemplos se encontram na Revue des Deux Mondes, de 1829, que pretendia promover vínculos culturais e políticos entre o mundo europeu e os "outros" mundos (americano, asiático e africano), tendo suas páginas publicadas na França e na América Latina (ROLLAND, 2005, p. 54); e nas revistas France Libre e Lettres Françaises publicadas em Buenos Aires durante a Segunda Guerra Mundial (ROLLAND, 2005, p. 381). Outros casos, destacados pela historiadora Claudia Gilman: a revista Nuevo Mundo (1966-1971), financiada pela Fundação Ford e fundada por Emir Rodríguez Monegal até 1968, momento em que mudou de diretor (de Emir Rodríguez Monegal a Horacio Daniel Rodríguez) e de endereço (de Paris a Buenos Aires) (GILMAN, 2012, p. 129); e a revista Libre (1971-1972), brevemente reunindo textos de intelectuais latino-americanos como Ariel Dorfman, Ángel Rama, Julio Cortázar, Mario Vargas Llosa e Octavio Paz, mas editada em Paris (GILMAN, 2012, p. 280-282). Na imprensa argentina, o jornalista Jacobo Timerman (1923-1999) se inspirou no francês Le Monde para fundar o diário La Opinión na década de 1970 (ULANOVSKY, 2011, p. 23). Por outro lado, há também revistas latino-americanas realizadas em Paris na virada do século XIX para o século XX, como La Estrella de Chile (1891), El Nuevo Mercurio (1907) de Gómez Carrillo, Mundial Magazine (1911) de Rubén Darío, La Revista de América (1912) de Francisco García Calderón e La Revue Sud-Américaine (1914) de Leopoldo Lugones (ROLLAND, 2005, p. 74).

6 Por perspectiva "transnacional" refiro-me a uma história não amarrada a visões metodológicas particulares, isto é, a história transacional pode perpassar a história política, cultural e intelectual, entre outras linhas. Refere-se mais a uma maneira particular de observar os objetos de investigação, pretendendo destacar relações, redes e processos pensados sem fronteiras, ou melhor, transcendendo as fronteiras do território nacional (PRADO, 2013, p. 19). Ver ainda PRADO, dezembro de 2005; WEINSTEIN, janeiro/junho de 2013. 
Monde Diplomatique, nas relações entre França e Argentina, revelou uma característica da revista como um veículo de circulação de ideias - no caso, circulação de ideias políticas.

Nestas páginas, busco ilustrar tais diálogos, contando com duas fontes históricas principais: por um lado, o arquivo histórico de edições impressas de Le Monde Diplomatique; por outro, diversas entrevistas realizadas com os principais intelectuais da gazeta em Paris e em Buenos Aires.7 Considero, com Jean-François Sirinelli, que os intelectuais não se definem por uma profissão ou uma titulação, mas por suas intervenções manifestadas no debate político - e, ao lado do historiador francês, considero as noções de geração, itinerário e sociabilidade para o estudo dos intelectuais (SIRINELLI, 1996). ${ }^{8}$ O estudo dos intelectuais que, vale dizer, encontra locus privilegiado na imprensa, um terreno frutífero para discussões políticas, enquanto mediador de ideias nos debates culturais, estéticos, estilísticos, intelectuais, ideológicos e políticos de nosso tempo. ${ }^{9}$

7 Quanto ao corpus: nestas páginas, destaco artigos das edições de Le Monde Diplomatique impressas entre julho de 1999 e fevereiro de 2011 que abordam relações entre França e América Latina. Além disso, a análise considerou entrevistas realizadas com os jornalistas e intelectuais de Le Monde Diplomatique na Argentina (Carlos Gabetta, Carlos Alfieri, Creusa Muñoz, José Natanson, Luciana Garbarino, Luciana Rabinovich e Pablo Stancanelli) e na França (Anne-Cécile Robert, Bernard Cassen, Dominique Vidal, Maurice Lemoine, Renaud Lambert e Serge Halimi). Assim, a partir da história oral como ferramenta metodológica, espera-se que as entrevistas se tornem fontes históricas relevantes para a compreensão do passado, ao lado de documentos impressos, documentos imagéticos e outros registros (ALBERTI, 2004; FERREIRA, 2002; FREITAS, 2006; MEIHY, 1998; MEIHY, HOLANDA, 2007).

${ }^{8} \mathrm{O}$ historiador observa que as solidariedades são um elemento importante nos círculos intelectuais - e é preciso considerar a geração, que costuma se formar a partir de um acontecimento fundador, permitindo construir uma memória coletiva para as trajetórias individuais. A análise do itinerário político, por sua vez, permite uma abordagem sobre o engajamento dos intelectuais. A sociabilidade, por fim, pode acontecer em torno da elaboração de uma revista, um manifesto, uma editora, passando também pela relação entre as dimensões afetivas e ideológicas, pois os comportamentos dos intelectuais são firmados não só por motivações filosóficas ou políticas, mas pela sensibilidade (SIRINELLI, 1996)

9 No Brasil, diversos estudos abordaram a imprensa como documento e como fonte principal para o historiador. Há uma importante bibliografia sobre a imprensa alternativa (uma impressionante experiência nacional nos tempos da ditadura civil-militar, com símbolos como Pasquim, Pif Paf e Movimento), sobre a imprensa tradicional (com questionamentos sobre as posições editoriais e políticas de "jornalões" como Folha de S.Paulo e O Estado de S. Paulo) e sobre as revistas político-culturais (não só nacionais, mas principalmente latino-americanas, como Lunes, Martín Fierro, Sur, entre outras). Entre outros, exemplos emblemáticos se encontram nas dissertações de Maria Helena Rolim Capelato e Maria Ligia Coelho Prado, publicadas no livro $O$ bravo matutino: imprensa e ideologia: O Estado de S. Paulo (1980); de Maria Aparecida de Aquino, versada no livro Censura, imprensa e Estado autoritário (19681978): O Estado de S. Paulo e Movimento (1999); e de Silvia Mikulin, com a investigação de Lunes no livro Cultura ilhada: imprensa e Revolução Cubana (1959-1961) (2003); e nas teses de Bernardo Kucinski, com Jornalistas e revolucionários: nos tempos da imprensa alternativa (1991); e de Beatriz Kushnir, com Cães de guarda: jornalistas e censores, do Al-5 à Constituição de 1988 (2004). Maria Helena Rolim Capelato ainda 


\section{Outro olhar}

Entre uma revista de atualidades e uma revue acadêmica, com artigos e ensaios longos, marcados por muitas notas, cronologias, dossiês, glossários, índices e referências bibliográficas, Le Monde Diplomatique pretende oferecer uma visão alternativa aos acontecimentos atuais, uma perspectiva crítica, um outro olhar ou, na expressão preferida pelos editores franceses, uma manière de voir.

Ficaram famosos os posicionamentos de Le Monde Diplomatique. Nas questões econômicas, destacou-se, por um lado, a crítica à globalização neoliberal e suas instituições tentaculares, como FMI e Banco Mundial; por outro, a esperança na sociedade civil e nos movimentos sociais para buscar alternativas, alterglobalização. Tanto na crise argentina de 2001 quanto na crise financeira internacional de 2008, os intelectuais se adiantaram meses, indicando contratempos adiante, lances arriscados e sinais de perigo no mercado, prestes a explodir. Após a explosão, continuaram martelando, em diferentes variações, a mesma ideia inicial: a chave para fugir da crise não estaria no mercado, simplesmente não poderia estar trancada na caixa preta própria a detonar a crise. Dever-se-ia procurar noutros cantos políticos, noutros canteiros civis. Deve-se procurar na política.

Entre o tom irônico e o sarcástico, entre a linha teórica e a jornalística, entre a perspectiva histórica e a análise contemporânea, os textos de Le Monde Diplomatique focam críticas às políticas imperialistas, tendo as diretrizes norte-americanas como alvo preferencial. Na revista, se a crítica econômica se foca no neoliberalismo, a crítica política privilegia o imperialismo. Além de se cruzarem em diversos momentos, essas dimensões são perpassadas ainda por outra crítica, midiática, que se refere ao próprio papel do intelectual e do jornalista.

Em julho de 1999, Le Monde Diplomatique imprimiu suas primeiras edições na Argentina arrastada por uma grave crise econômica, com uma dívida externa na casa dos 100 bilhões de dólares e mais de 2,5 milhões de desempregados, levando à renúncia do presidente Fernando de la Rúa em dezembro de 2001, após dias de violência e 
manifestações nas ruas de Buenos Aires. Nesse território turbulento, a edição argentina angariou muitos leitores que buscavam uma perspectiva diferente, alternativa, sobre a crise. Na mesma linha, a revista francesa liderada pelo sociólogo espanhol Ignacio Ramonet se destacou por abraçar ideias de momentos críticos como os protestos de Seattle (1999) e os primeiros passos para os fóruns de Porto Alegre (2001).

Le Monde Diplomatique aportou na Argentina graças à iniciativa do jornalista argentino Carlos Gabetta, ex-militante do Ejército Revolucionário del Pueblo (ERP) exilado na França pouco tempo depois do golpe que derrubou Isabel Perón, em 1976. Exilado, Gabetta escreveu para diversas publicações, como o francês Politique Hebdo e o italiano Il Manifesto. A partir de 1977, graças ao amigo Bernard Cassen, Gabetta passou a colaborar com Le Monde Diplomatique, especialmente sobre temas econômicos e políticos latino-americanos, e logo tornou-se amigo de Claude Julien e Ignacio Ramonet. De volta à Argentina, Gabetta reuniu energia e esforços econômicos para viabilizar a nova edição, que dirigiu entre 1999 e 2011.

Na edição de julho de 2000, El Dipló publicou um dossiê especial França Argentina. No dossiê, o sociólogo Eric Calcagno introduzia a ideia das relações antigas entre as duas culturas, que, na sua expressão, teriam todos os ingredientes para escrever um "romance":

Não faltam em dois séculos nem militares, nem escritores e viajantes, nem artistas, arquitetos e pensadores que não possam ser os protagonistas de uma ficção maior que abarque ambas margens. A sensação de influências, nutrida de clichês (um galicismo aceitado), articuladas em mitos individuais, de Santiago de Liniers a Jean-Paul Sartre, ou coletivos, como Carlos Gardel, termina às vezes por ofuscar as dimensões de uma realidade complexa. [...] Talvez olhar-se no espelho do outro seja um exercício pertinente, não para a importação de soluções prontas para usar, que não sobrevivem à diferença de histórias e de contextos, mas para nutrir a reflexão com uma nova perspectiva aos próprios desafios. Não é um exercício fácil, mas "às vezes é preciso se afastar das coisas, pôr um mar no meio, para ver as coisas de perto", tal como escrevia Alejo Carpentier em seu Concierto Barroco. (CALCAGNO, 2000)

Olhar-se no espelho do outro. A expressão do economista se enquadra perfeitamente para as relações imbricadas entre Le Monde Diplomatique e El Dipló, nos seus metadiscursos marcados por metáforas visuais: o outro olhar, o punto de vista 
presentes; de outro, compreender como os intelectuais argentinos contemplam a história francesa, seu legado revolucionário e seu farol civilizatório.

A ideia do dossiê, portanto, era iluminar as dimensões dessa realidade complexa, a partir de três eixos: cultura, economia e sociedade. Enquanto o economista Alfredo Calcagno lembrava a escola francesa de regulação econômica, o escritor Pedro Sondereguer perambulava na influência francesa na vida urbana argentina. Enquanto a jornalista Silvia Hopenhayn comentava o contexto e as influências da literatura francesa, o historiador Gregorio Weinberg abordava o modelo francês na história das ideias.

Intelectual e historiador argentino, Gregorio Weinberg (1919-2006) cita a difusão do iluminismo e da intelligentsia francesa, do romantismo social e do utopismo que deixaria vestígios em diversos pensadores latino-americanos, como Esteban Echeverría (1805-1851) e Juan María Gutiérrez (1808-1878), assim como em Domingo Sarmiento (18181888) e Juan Bautista Alberdi (1810-1884). Dali, o historiador salta para o século XX, com a influência intelectual de Jean-Paul Sartre (1905-1980) e Maurice Merleau-Ponty (19081961), depois de Claude Lévi-Strauss (1908-2009), Jacques Lacan (1901-1981) e Michel Foucault (1926-1984), entre outros - autores presentes, diz Weinberg, na ponta da língua de todos os intelectuais e estudantes de humanidades na Argentina e no resto da América Latina. Volta no tempo para citar ainda historiadores, como Alexis de Tocqueville (1805-1859), Felicité de Lamennais (1782-1854) e François Guizot (1787-1874), Marc Bloch (1886-1944) e Lucien Febvre (1878-1956), Fernand Braudel (1902-1985) e Jacques Le Goff (1924-2014), a ponto de notar que o index seria interminável ao ampliar o campo para outras disciplinas. Entretanto, Weinberg assinala o momento primeiro para a influência intelectual francesa na Argentina com o revolucionário de mayo Mariano Moreno (17781811), que traduziu e difundiu $O$ contrato social de Jean-Jacques Rousseau para insuflar 0 “espírito republicano” na ex-colônia ibérica, em 1810 (WEINBERG, 2000).

Outro paralelo possível entre França e Argentina se encontra no editorial de Carlos Gabetta de novembro de 2010. O editor traça uma linha entre as agitações sociais na 
França, tendo como fio condutor a crise financeira, e o imperativo de repensar a política na Argentina. No editorial "París/Buenos Aires", diz que a resposta "fácil” diante das diversas manifestações de insatisfação popular francesas seria: "Se as coisas estão tão mal que até na França acontecem enfrentamentos desse calibre, por que a Argentina deveria ser uma exceção?" A resposta mais fértil, mas mais difícil, implicaria analisar a realidade argentina, pois o que importaria, diante das crises, é o estado das ferramentas institucionais de um país. Outras sociedades, como a francesa, talvez pudessem enfrentar a crise melhor e propor alternativas, mas não a argentina peronista, uma vez amarrada no estéril enfrentamiento de siempre. Para Gabetta, a menos que um governo, pressionado por sua sociedade - o que valeria tanto para a França quanto para a Argentina - se atreva a mudar radicalmente os rumos, a crise financeira internacional poderia acabar com as democracias e a paz mundial - a menos que antes acabe com o capitalismo (GABETTA, 2010, p. 2).

Foram impressas diversas discussões nesse estilo. Em maio de 2007, Gabetta voltava a traçar paralelos. Para Gabetta, tanto França quanto Argentina consolidam alianças políticas fortes, à direita e à esquerda, mas que disputam na realidade o que se pode compreender como o centro, um magma de ideologias e de interesses de setor altamente volátil. Nos dois países, o editor vê fortes contradições políticas, de interesses e de lideranças, assim como frequentes movimentações e vaivéns no selar e romper alianças. Na França, vê desemprego estrutural e pressões imigratórias, conflitos sociais, insegurança urbana, declive econômico e industrial, descontento e desesperança. $\mathrm{Na}$ Argentina, vê um declive mais grave, após décadas de violência e irresponsabilidade, marcada por miséria e retrocesso econômico, científico, institucional. "Poderia adicionar que nos dois países é visível o afã cidadão de manter e consolidar o sistema democrático, mas isso seria forçar a barra, porque o que na França é um exercício da vida toda, entre nós ainda é uma acrobacia difícil, algo que praticamos com dificuldade, ainda que agora com dedicação. Os franceses ainda confiam em suas instituições; os argentinos não têm razões para tal” (GABETTA, 2007, p. 3).

Ponto primordial para tal, na perspectiva de Carlos Gabetta, é o surgimento do peronismo, que suscitou ódios liberais e populistas. E o movimento social, nesse momento argentino atual, transbordaria o populismo e o liberalismo, querendo outro 
tipo de participação democrática e pedindo perdidos níveis de igualdade. Mas tanto populistas quanto liberais estariam compartilhando os mesmos métodos, disputando os mesmos alvos sociais.

Ainda nessa edição, Ignacio Ramonet escreveu sobre o populismo francês, enganchado no triunfo de Nicolas Sarkozy - uma direita agressiva, "brilhante e orgulhosa" - a 6 de maio de 2007, contra a socialista Ségolène Royal. Para Ramonet, Sarkozy mesclaria voluntarismo e autoridade, personalização e provocação, nacionalismo e liberalismo, conjugados talento, retórica e um domínio temível das mídias - arenas em que, sem timidez, arbitrou a discussão sobre as linhas limítrofes entre direita e esquerda. Na composição de seu primeiro gabinete, destaca o editor, o perímetro da direita incluiria agora parte do Partido Socialista, na sua ala "social-liberal”, numa paradoxal direitização da esquerda francesa. Seria o fim do gaullismo, dando lugar ao sarkozismo, "um populismo francês que se propõe a reunir no bojo a todas as direitas, dos lepenistas aos sociais-liberais, sem esquecer os centristas, cativando-as mediante uma ilusão de movimento e de abertura qualificados como 'modernos' e ainda 'progressistas"' (RAMONET, 2007, p. 40).

Ramonet interpreta o fracasso da esquerda como uma derrota intelectual, por não ter produzido, por imobilismo ou por incompetência, uma nova teoria política. A esquerda teria perdido essa batalha das ideias, após, uma vez no poder, tolher salários e fechar fábricas, liquidar setores industriais e leiloar serviços públicos. O sociólogo critica ainda os que atribuem a culpa do fracasso à mídia - o que seria lamentação infantil e incompetência - pois antes da mídia mercenária, quem dita as regras é o poder dos mercados. Para Ramonet, por fim, as esquerdas se veriam diante de uma derrota de decisiva, um fim de época. Se quiserem voltar aos trilhos da história, será preciso repensar e refundar suas ideias a fim de construir, "como se diz nesses tempos na América Latina", diz o editor, um socialismo do século XXI (RAMONET, 2007, p. 40).

Nas primeiras e na última página de Le Monde Diplomatique Edición Cono Sur de maio de 2007, portanto, se veem refletidos os dois lados do espelho. Para Gabetta, a Argentina com as sequelas do peronismo, incapaz de confiar nas suas instituições - bem diferentes dos franceses, tão politizados, tão cívicos, num ideal de republicanismo 
revolucionário do século XVIII. Para Ramonet, a França iludida com a lábia do sarkozismo, uma direita a ofuscar uma esquerda fracassada - bem diferente dos latino-americanos, tão críticos e avant-garde, num socialismo revolucionário do século XXI.

Na perspectiva do jornalista argentino, os intelectuais europeus, especialmente franceses, encontraram fontes de esperança nos territórios latino-americanos, diante das desilusões da esquerda europeia. Era o giro a la izquierda a marcar a efervescência da América Latina "rebelde".

\section{América rebelde?}

Um giro a la izquierda, na expressão do historiador Carlos Aguirre. Uma década, diversas ascensões de governos progressistas, com movimentos e líderes identificados com posições antineoliberais e tom anti-imperialista, que reivindicam parcialmente as pautas políticas e sociais das tradições socialistas e socialdemocratas na América Latina. Que rumam à descolonização cultural, econômica e política dos povos latino-americanos. Que simbolizam uma mudança transcendental em relação às décadas anteriores em que predominaram ditaduras, isto é, governos burocráticos e autoritários, e modelos democráticos restritos, pautados pela economia neoliberal. Que, com o militar Hugo Chávez na Venezuela (1998), o metalúrgico Luiz Inácio Lula da Silva no Brasil (2002), o peronista Néstor Kirchner na Argentina (2003), o cocaleiro Evo Morales na Bolívia (2005), a médica Michelle Bachelet no Chile (2005), o economista Rafael Correa no Equador (2006), o médico Tabaré Vázquez e o ex-guerrilheiro José Pepe Mujica no Uruguai (2004 e 2009), apesar das diferenças de estilos e trajetórias, inclinaram à esquerda seus mandatos presidenciais, distanciando-se do consenso de Washington. Que, assim, lideraram uma revisão da ortodoxia neoliberal na economia, articularam políticas de direitos humanos, amenizaram a miséria com políticas sociais. Que, apesar dos pesares, propõem alternativas radicalmente distintas à hegemonia do capital, ainda são alvo para discussões, considerando as perguntas pendentes que só o tempo poderá responder - e, por trás dessas interrogações, um questionamento capital: o que é ser de esquerda na América Latina do século XXI? (AGUIRRE, 2009, p. 1). 
Para Aguirre, partindo das tradições marxistas revolucionárias, as agendas atuais das esquerdas abrigariam um anti-imperialismo militante (às vezes mais retórico que real), um nacionalismo (presente na defesa dos recursos naturais e das soberanias nacionais), um esforço na redistribuição da riqueza e propostas de organização independente dos setores populares - e, assim, se distanciaram dos antigos modelos políticos e econômicos centralistas e autoritários identificados com os partidos comunistas (AGUIRRE, 2009, p. 4).

Sociólogo italiano e latino-americanista, Massimo Modonesi marca a mudança de época, paradoxalmente, diz, justificada pelo fim da história ${ }^{10}$ - que, como lenda, atrás da euforia triunfalista a inspirá-la, contém certo fundo de verdade. Entre fins da década de 1970 e princípios da década de 1990, findaria um ciclo histórico iniciado nos primeiros atos do século XX: um ciclo de lutas políticas e sociais de inspiração anticapitalista, antiimperialista e socialista, que disputavam o poder em diversas dimensões. Um ciclo, diz Modonesi, que incluía momentos de crise e de equilíbrio da estrutura de dominação. Assim, a década de 1980 assistiria à dissipação de um modelo de conflito - e os vencedores se apressaram a declarar o fim de todo conflito, por convicção ou por intenções de injetar um quê psicossocial que intoxicaria o imaginário coletivo e marcaria uma visão de época. Na América Latina, isso se intensificaria a partir de três fatores: o militarismo, o eleitoralismo e o neoliberalismo.

Por militarismo, o sociólogo italiano se refere certamente aos golpes e ditaduras latino-americanas - Argentina, Brasil, Chile, Paraguai, Uruguai. Por eleitoralismo, o autor se refere aos rumos das transições democráticas, que consolidaram a ideia da democracia eleitoral como o "melhor" dos mundos possíveis. E, no marco da alternância sem alternativa, o neoliberalismo pôde se firmar como consenso inevitável com a impressão

\footnotetext{
10 Para o filósofo nipo-americano Francis Fukuyama, o capitalismo liberal seria o nec plus ultra da vida política e econômica da história. No seu ensaio de 1989, o fim da história não teria no capitalismo um sistema "perfeito", mas eliminaria quaisquer alternativas melhores a esse sistema. A partir do ensaio The end of history?, que tomaria corpo no livro The end of history and the last man (1992), o filosófo afirma que, com o desenvolvimento científico, técnico e tecnológico, os tempos modernos obrigariam todos os Estados a se modernizar, se quisessem sobreviver às pressões das potências mais avançadas, abrindo horizontes ilimitados de desenvolvimento econômico para satisfazer necessidades materiais - e o capitalismo, nesse ínterim, seria o único sistema "possível". Ver, entre outras, a crítica do historiador marxista Perry Anderson, O fim da história: de Hegel a Fukuyama (1992).
} 
de pluralismo político. "Foram os anos do 'pensamento único' nos quais a alternância política confirmava a ausência de alternativa sócio-econômica" (MODONESI, 2009, p. 157) - interessante escolha de expressão do autor, citando a ideia consagrada nos editoriais de Ignacio Ramonet.

Identificar o modelo neoliberal foi o primeiro passo para desmantelar o sistema modelo que passou a ocupar o centro de diversas discussões de partidos e movimentos de oposições, de intelectuais latino-americanos. Por volta de 1994, com o levante zapatista de Chiapas, essa visibilidade política conquistaria contornos mais nítidos, com as primeiras movimentações de uma resistência declaradamente antineoliberal - de Chiapas ao MST no Brasil, os cocaleros na Bolívia, os piqueteros na Argentina, que desembocaria nas manifestações de Seattle no amanhecer do movimento altermundialista e nos fóruns de Porto Alegre. Na interpretação do teórico, isso marcaria um novo ciclo de mobilização, fator que mudaria a ordem real e simbólica, provocando um horizonte de crise hegemônica - o que impactaria nas urnas, ocasião oportuna para o protagonismo de políticos antineoliberais ou, no mínimo, não tão identificados com o neoliberalismo.

Entre épocas, arrematado o momento hegemônico do neoliberalismo, ainda resiste a dominação neoliberal. Nessa arena conflitiva, as crises econômicas e políticas descortinam um palco potencial para o antagonismo como fenômeno a transcender suas balizas estruturais e protagonizar processos de transformação. Nesse capítulo efervescente da história do tempo presente, Massimo Modonesi indica a incerteza dos desenlaces, a partir de interrogações de inspiração gramsciana: "Como soldar o presente ao futuro, satisfazendo as necessidades urgentes do presente e trabalhando utilmente para criar e 'antecipar' o futuro? Como projetar o presente ao futuro? Como prefigurar nas lutas de hoje a sociedade de amanhã?" (MODONESI, 2009, p. 177).

Tempos diferentes, épocas diferentes. A fim de compreender esse giro a la izquierda na América Latina, seus símbolos, seus movimentos e suas possibilidades, vale folhear e destrinchar as páginas, argentinas e francesas, de Le Monde Diplomatique.

Três edições da revista bimestral Manière de voir, especialmente compilando artigos antigos de Le Monde Diplomatique presentes na matriz francesa, focaram 
questões latino-americanas: em novembro/dezembro de 1997, Amérique Latine, du 'Che' à $\operatorname{Marcos}\left(n .^{\circ} 36\right)$; em junho/julho de 2003, L'Amérique Latine en effervescence (n. $\left.{ }^{\circ} 69\right)$; e em dezembro de 2006/janeiro de 2007, Amérique Latine rebelle (n. $\left.{ }^{\circ} 90\right)$.

No editorial de Manière de voir n. ${ }^{\circ}$ 90, na virada para 2007, Ignacio Ramonet definia o momento latino-americano com a hiperbólica expressão age d'or. Parte da hipótese de que, ao longo de sua trágica história desde o século XIX, a América Latina viveria agora um marcante tempo de paz, prosperidade e, principalmente, consolidação democrática. Elenca as vitórias, entre eleições e reeleições, de candidatos de esquerda ou centro-esquerda na região: Hugo Chávez na Venezuela, Lula no Brasil, Néstor Kirchner na Argentina, Tabaré Vázquez no Uruguai, Evo Morales na Bolívia, Martín Torrijos no Panamá, Michelle Bachelet no Chile - e inclui Alan García no Peru, justificando, pois seu partido, a Aliança Popular Revolucionária Americana (APRA), integra a Internacional socialista.

Vitórias inéditas, mantidas dentro das regras do jogo democrático. Ramonet lembra que, sob pretextos diversos, projetos progressistas foram interrompidos por golpes militares ou intervenções diretas dos Estados Unidos na região. Ilustra o argumento com as situações de Jacobo Arbenz na Guatemala, João Goulart no Brasil, Juán Bosch na República Dominicana e Salvador Allende no Chile - derrubados em 1954, 1964, 1965 e 1973, por golpes militares endossados pelos Estados Unidos no contexto da Guerra Fria. Contexto em que uma única experiência se manteria: Cuba, mas ao alto custo de um embargo comercial devastador e de diversas querelas, como a crise dos mísseis de outubro de 1962. Ramonet questiona por que projetos progressistas, que por décadas foram minados, agora voltam a marcar a América Latina - e "por que uma vaga rosa e vermelha pode cobrir tantos Estados sem ser interrompida como antes?" (RAMONET, 2006/2007, p. 4). O que mudou?

Primeiro, o fracasso das experiências neoliberais latino-americanas na década de 1990 - que, na interpretação do autor, teriam saqueado esses países, arrastando suas sociedades à pobreza e suas indústrias nacionais à bancarrota, levando, finalmente, seus povos à revolta. Aí, uma interessante escolha de exemplo do editor espanhol: a revolta popular na Argentina, de 21 de dezembro de 2001, que provocou a renúncia do presidente 
Fernando de la Rúa, e principalmente o colapso das políticas neoliberais de Carlos Menem entre 1989 e 1999 - revolta na América Latina que corresponderia na Europa ao simbolismo da queda do muro de Berlim, de 9 de novembro de 1989, isto é, a recusa de um modelo dogmático.

“É um Quixote, mas não está louco". Carlos Gabetta cita a frase de Bonaparte, a respeito do general-libertador venezuelano Francisco de Miranda, para marcar suas impressões sobre diferentes líderes latino-americanos: Chávez, Fidel, Lula e Kirchner. Justifica que a mídia, os intelectuais de direita e certos intelectuais da esquerda socialdemocrata costumam caracterizar como quijotadas, isto é, como delírios, iniciativas desses governantes: Venezuela, a soberania diante dos Estados Unidos, que mira seu petróleo; Cuba, a soberania, também a tiro de piedra dos Estados Unidos, que ainda não teria engolido a perda de sua isla-cabaret; Brasil, rebelde que ousou tirar 50 milhões da fome; Argentina, maré mafiosa que pretende se tornar um país "sério". Crítico, porém, das possíveis ilusões suscitadas por esses governantes, Gabetta considera que, na realidade, o único razoável seria uma modesta utopia. Que as sociedades latinoamericanas ainda lutam por sua independência política real. Que diante do pessimismo atual, diagnosticado com desigualdades crônicas, desemprego agudo, especulação febril, Estados desorientados, conflitos armados, desordens climáticas e pandemias, esses pujos revolucionários corresponderiam a uma nova onda independentista. Nesse viés, Chávez, Fidel, Lula e Kirchner lembrariam quixotes, mas não estariam loucos. Deveriam honrar os valores de libertad, igualdad e solidariedad - e é relevante a escolha de expressões do editor, invocando os ideais franceses tão simbólicos de liberté, egalité e fraternité (GABETTA, 2004, p. 3).

Eis a América Latina do século XXI: vibrante, mas carregada de contradições. E, num viés marxista, a esquerda teria virado "a página do livro" do momento em que o capitalismo teria dado tudo de si. E a atual esquerda encontraria na América Latina um terreno fértil para cultivar outras experiências: um eixo Bolívia-Cuba-Venezuela com propostas socialistas, outro de Argentina, Brasil, Chile, Equador, Paraguai e Uruguai com 
alternativas dentro do capitalismo, mais distributivo e mais harmônico. Todos com altas possibilidades, mas limites imediatos. Entre otimismos e pessimismos, entre oportunidades e colapsos, entre alternativas vibrantes e vias contraditórias, um "fim de época":

A muitos, a muitíssimos, esse ponto de vista continua parecendo uma ingenuidade, um wishfull thinking sofisticado, mas não sentem vocês, simplesmente lendo atentamente os bons jornais, que estamos vivendo um tormentoso, violento, confuso, imprevisível e apaixonante fim de época? [...] A América Latina tem todas os ativos para sair adiante. Riquezas, território e unidade cultural; campesinos, metalúrgicos, classes médias, cientistas e intelectuais produto de um trânsito marginal e caótico, mas trânsito por fim, para a modernidade. Tempos duros e apaixonantes, que pedem por estadistas e visionários da história antes que políticos que podem deixar passar a oportunidade. (GABETTA, 2004, p. 3)

Para Gabetta, a ascensão das esquerdas latino-americanas nos processos democráticos atuais muito diferem das décadas de 1960 e 1970, pois quase inexistem movimentos armados importantes a pedir a destruição da ordem burguesa e o socialismo revolucionário. Eleitos democraticamente, esses governos pretenderiam aprofundar e consolidar a democracia, erradicando desigualdades - e isso, sim, seria revolucionário. Logo, nessas democracias revolucionárias, as forças armadas e as intervenções militares não seriam mais o fator de desequilíbrio, mas as pressões dos lobbies políticos, da especulação financeira e da difamação midiática. A fim de empreender transformações revolucionárias, essas democracias precisariam enfrentar, ou no mínimo contornar, tais pressões - uma tarefa hercúlea, mas promissora e apaixonante: “Em todo caso, algo pelo qual nos próximos anos valerá viver e lutar na América Latina" (GABETTA, 2006, p. 2-3).

Nem tudo são flores no terreno latino-americano, obviamente. Nas páginas platinas de Le Monde Diplomatique, Carlos Gabetta e Ignacio Ramonet escreveram diversos textos sobre as atuais possibilidades da América Latina. Questões mais sensíveis evidenciam contradições e discordâncias entre seus intelectuais, como Cuba e Venezuela, com seus controversos comandantes, Fidel Castro e Hugo Chávez. 


\title{
(Entre)linhas
}

Diante do labirinto europeu, uma luz latino-americana. Diante do mosaico latinoamericano, um farol francês. Nesses caminhos cruzados, entrelaçados, tropeçados, vale destacar os nós entre Le Monde Diplomatique e sua América Latina rebelde. Além das linhas nas fontes impressas, é interessante mirar as entrelinhas reveladas nas oralidades dos intelectuais de Le Monde Diplomatique.

De sua herança terceiro-mundista, Le Monde Diplomatique acompanhou a realidade latino-americana desde as ditaduras. Lembrando o passado, a editora francesa Anne-Cécile Robert destaca o interesse francês pela teologia da libertação, pelos movimentos fervilhantes ao redor de Che Guevara e Fidel Castro, e por "escritores de envergadura universal, com uma relação à justiça social muito forte nos povos latinoamericanos". ${ }^{11}$ Pensando o presente, diz:

\begin{abstract}
Atualmente nós estamos muito admirados da luta excepcional dos povos latino-americanos para se libertar do ultra-liberalismo e da dominação americana dos Estados Unidos. Isso é um exemplo, nós consideramos, para o mundo inteiro - mesmo se somos críticos de algumas derivações e alguns erros de alguns regimes. A América Latina é muito interessante e muito importante para nós, pois é um laboratório da liberdade. ${ }^{12}$
\end{abstract}

$\mathrm{Na}$ visão de Anne-Cécile Robert, a América Latina suscitou e suscita muito interesse para Le Monde Diplomatique, como uma "fonte de ensinamento" que seduziu os intelectuais franceses, que viram ali uma busca de transformação social por esquerdas ancoradas na democracia. Uma lupa nesta visão: as expressões da editora, "fonte de ensinamento" e seduziu. Para Robert, a Europa viveria tempos muito diferentes da América Latina - estaria congelada dentro da União Europeia, onde a possibilidade para buscar alternativas e transformação social seria muito mais complicada.

O ex-editor francês Bernard Cassen, por sua vez, adiciona um fator paralelo: após três décadas, a ideologia liberal teria convencido os intelectuais europeus, especialmente franceses, de que não era possível mudar. "No alternative, é assim como é, é preciso se

\footnotetext{
${ }^{11}$ Anne-Cécile Robert em entrevista concedida à autora no dia 14 de outubro de 2014.

${ }^{12}$ Anne-Cécile Robert em entrevista concedida à autora no dia 14 de outubro de 2014.
} 
ajustar à mundialização, ao mercado. Essa visão liberal assolou as consciências e os espíritos". ${ }^{13}$ Assim, mirar a América Latina Ihes teria permitido ver o mundo por outro prisma: a partir de Hugo Chávez, os governos progressistas mostrariam que é possível dizer "não" - ao imperialismo e ao neoliberalismo, isto é, aos Estados Unidos, ao Banco Mundial, ao Fundo Monetário Internacional. “É revolucionário dizer 'não”, diz. Por linhas paralelas às de Robert, Cassen diz: "Se, em geral, é a América Latina que imita a Europa, lá nós vimos que havia ensinamentos a tirar das experiências latino-americanas". ${ }^{14}$

O editor francês Renaud Lambert se afina a tais ideias, mas com tons diferentes. $\mathrm{O}$ editor compreende a importância da América Latina para Le Monde Diplomatique a partir de elos externos e internos. Quanto aos internos, destaca a presença de notáveis latinoamericanistas na revista: Bernard Cassen, Ignacio Ramonet, Maurice Lemoine. Além deles, Claude Julien, que transformaria Le Monde Diplomatique a partir de 1973, na época em que Augusto Pinochet tomava o poder no Chile, gatilho para a contrarrevolução neoliberal - e assim se poderia compreender por que o magazine, ancorado na defesa do Terceiro Mundo e dos povos oprimidos do hemisfério sul, se virou para a América Latina. Nos elos externos, isto é, a própria realidade latino-americana, a maré de ideias progressistas teria tornado esses territórios uma "zona rica de esperança", "um contraponto importante frente à lógica imposta na Europa de que não há alternativa ao modelo neoliberal". ${ }^{15}$

É preciso precisar. Quando digo que a América Latina se tornou uma fonte de esperança, penso na América Latina no período que se inicia com a eleição de Hugo Chávez na Venezuela [em 1998] e que penso que se encerre neste momento [atual]. A América Latina encontra dificuldades agora, que não conhecia em 2005 ou em 2000. O cenário latino-americano parece mudar, mas quando digo que se tornou uma fonte de esperança, refiro-me à América Latina entre os anos 2000 e 2010 principalmente. Uma época que, na França e outros lugares, o Partido Socialista nos explicava que o Estado não pode tudo. Na mesma época, na Venezuela, por exemplo, Hugo Chávez mostrava que o Estado, mesmo se podia tudo, podia muito. E podia sobretudo ajudar a esquerda a mudar o mundo. Para responder à sua questão: sim, parece-me que houve uma alternância. E que as ideias outrora fundadas pela esquerda,

\footnotetext{
${ }^{13}$ Bernard Cassen em entrevista concedida à autora, no dia 10 de novembro de 2014.

${ }^{14}$ Bernard Cassen em entrevista concedida à autora, no dia 10 de novembro de 2014.

${ }^{15}$ Renaud Lambert em entrevista concedida à autora, no dia 2 de outubro de 2014.
} 
no governo - no caso da França, do Partido Socialista - foram esquecidas. E essas ideias foram defendidas em outra parte do mundo, que reivindicavam uma história comum, da Revolução Francesa, da Comuna de Paris, da Revolução Cubana no caso do combate latinoamericano. $^{16}$

É importante destacar a resposta de Lambert, um intelectual mais jovem, mas talvez mais ponderado que seus companheiros Cassen e Ramonet. Apesar de ver na América Latina uma "fonte de esperança” para as esquerdas, o editor observa os limites de suas possibilidades. Entretanto, é interessante marcar outro ponto de seu contraponto: as ideias da esquerda, se esquecidas por socialistas francesas, reverberaram, frutificaram, brotaram em outra parte do mundo, no território latinoamericano que reivindicaria uma história comum: da Revolução Francesa, da Comuna de Paris, da Revolução Cubana.

O diretor francês Serge Halimi destaca o interesse antigo do Monde Diplomatique pela América Latina, desde os movimentos revolucionários, a vitória de Cuba, os movimentos contrarrevolucionários, o golpe no Chile. Agora, justifica o interesse presente pelas experiências latino-americanas positivas, consideradas tentativas, maiores ou menores, de fugir do modelo neoliberal. “É por isso que observamos a América Latina. Nós não procuramos os modelos lá fora, mas nós sabemos que os modelos não são necessariamente os exemplos de regressão social dos Estados Unidos e da Europa". ${ }^{17}$

O ex-editor francês Dominique Vidal assinala criticamente uma moda intelectual très française diante da América Latina - um frisson otimista relacionado a Chávez, especialmente. Vidal critica seus amigos, Cassen e Ramonet, que não teriam escapado a essa adoração de ídolos:

Direi como penso francamente. Pas faire de la langue de bois [sem conversa fiada], como dizemos. Há dois tipos de intelectuais que não podem compreender os fenômenos latino-americanos, como o peronismo e o bolivarianismo. O primeiro tipo corresponde a intelectuais anticomunistas, cujo anticomunismo é tal que é incompreensível, por exemplo, ao correspondente do Monde o que acontece na Venezuela. $\mathrm{O}$

\footnotetext{
${ }^{16}$ Renaud Lambert em entrevista concedida à autora, no dia 2 de outubro de 2014, grifo meu.

17 Serge Halimi em entrevista concedida à autora, no dia 28 de novembro de 2014.
} 
segundo tipo corresponde aos que sempre precisam de um ídolo. Foi Mao Tse Tung durante a revolução cultural, Che Guevara durante "um, dois, três Vietnãs". Os que tiveram uma certa adoração por Gorbachev ou por Ho Chi Mihn. Todos que, na minha opinião, têm um "prócomunismo" tão forte não podem compreender, pois têm uma visão acrítica. Vivemos num momento de convulsão mundial tal (nas forças internacionais, enfraquecimento da hegemonia americana, crise europeia, crise financeira internacional, desaparecimento da alternativa comunista antiga) que, se não temos uma visão crítica, estamos perdidos. Por muito tempo, o que se escreveu nos jornais e no Monde Diplomatique sobre Venezuela ou sobre Cuba... ${ }^{18}$

Vidal pondera que essa situação mudou no Le Monde Diplomatique, após as saídas de Maurice Lemoine e Ignacio Ramonet, ambos aposentados. "Um jornalista mais jovem, Renaud Lambert, é tipicamente o caso: teve seu momento de adoração por Chávez, mas agora tem uma visão mais crítica", ressalva. ${ }^{19}$

Deste lado do Atlântico, o ex-diretor argentino Carlos Gabetta também viu essa faísca de esperança, mas com outros olhos:

[...] uma esperança que nasceu justamente da desorientação da esquerda europeia. Isso vale para a ala de esquerda que representa Le Monde Diplomatique. Eles não sabem o que fazer com sua própria realidade e por isso miram as experiências latino-americanas, porque consideram que esses governos têm apoio popular, mas não têm. Esses governos, autoritários e corruptos, abandonaram a ideia de esquerda. Gostaria que Le Monde Diplomatique recuperasse sua atitude crítica. ${ }^{20}$

Gabetta pediu demissão de Le Monde Diplomatique após desentendimentos com o empresário Hugo Sigman, proprietário da editora Capital Intelectual, que publica a revista. Segundo Gabetta, Sigman é peronista e muito favorável ao governo de Cristina Kirchner - ao passo que o jornalista faz severas e diversas críticas ao peronismo e a Cristina Kirchner.

Em setembro de 2012, Carlos Gabetta me recebeu no seu apartamento no bairro de San Telmo, Buenos Aires. Lembrou com carinho seus tempos d’El Dipló e sua determinação, talvez teimosia, para fazer vingar o projeto. Questionei como o jornalista

\footnotetext{
${ }^{18}$ Dominique Vidal em entrevista concedida à autora, no dia 6 de outubro de 2014 .

${ }^{19}$ Dominique Vidal em entrevista concedida à autora, no dia 6 de outubro de 2014 .

${ }^{20}$ Carlos Gabetta em entrevista concedida à autora, no dia $1^{\circ}$ de setembro de 2014 .
} 
analisava a edição argentina atual, após sua saída. O ex-diretor respondeu: "Continua sendo uma ótima publicação. Os 70\% continuam sendo traduções literais dos artigos franceses - isto é, o mesmo que fazíamos na minha época como diretor. E os artigos argentinos são bons". No entanto, ponderou: “Muitas vezes publicam notas interessantes, mas que não refletem a realidade do país. Principalmente as notas mais alinhadas ao kirchnerismo, que perderam a perspectiva crítica. Não estou dizendo por ressentimento, mas com franqueza". ${ }^{21}$

Em setembro de 2014, voltei a Buenos Aires, onde reencontrei Carlos Gabetta num café na Avenida Brasil. O jornalista se declarou radicalmente oposto ao peronismo. Disse ainda não considerar o kirchnerismo à esquerda e, tal como a crítica presente nos seus editoriais, relevou a presidência de Néstor Kirchner, que teria atuado com certo realismo e uma perspectiva progressista, pois a realidade Ihe empurrava a isso. Cristina Fernández, por sua vez, teria se revelado arbitrária, envolvendo-se com políticos corruptos. Questionei novamente sua análise sobre a edição argentina de Le Monde Diplomatique - e sua resposta foi muito mais severa:

Leio a edição francesa, pois, francamente, o que se publica na edição argentina não me interessa. É sociologia vulgar. [...]. O que acontece é o seguinte: Le Monde Diplomatique, tanto o francês quanto o argentino, embarcou em apoiar movimentos populistas. A Cristina Kirchner na Argentina, a Hugo Chávez na Venezuela, a Rafael Correa no Equador. Ressalvo: são [governos e líderes] distintos, certamente. [Mas] saí do Le Monde Diplomatique por isso. Hugo Sigman, o proprietário da empresa [a editora Capital Intelectual] e da franquia, passou a me provocar problemas, pois eu criticava muito o governo. Em outro momento, eu tinha elogiado muitíssimo, tinha escrito notas muito elogiosas sobre Cristina Fernández durante sua primeira campanha. Mas depois o governo mudou. Isso complicou meu papel de jornalista. Nós podemos errar. Mas é preciso dizer que está bem o que está bem, que está mal o que está mal. Se erramos, admitimos e pedimos desculpas. $O$ diretor não queria de nenhuma maneira que eu criticasse Cristina Fernández. Nem o governo espanhol, pois ele mantém negócios com Felipe Gonzalez e o rei espanhol. Eu disse "não". E precisei ir embora. Os franceses o apoiaram, pois também estão nessa posição. Eles apoiam Hugo Chávez e Cristina Fernández. Não concordo com esse populismo. Em vez de continuar estudando os acontecimentos, criticando o que é preciso criticar e apoiando o que é preciso apoiar...22

\footnotetext{
${ }^{21}$ Carlos Gabetta em entrevista concedida à autora, no dia 11 de setembro de 2012.

${ }^{22}$ Carlos Gabetta em entrevista concedida à autora, no dia $1^{\circ}$ de setembro de 2014 .
} 


\section{O lado da trincheira}

Outubro, 1991. Mais de $40 \mathrm{mil}$ indígenas ocupam as ruas guatemaltecas de Quetzaltenango, bradando entre tambores, flautas e acordeões: "Se ve, se siente, el pueblo está presente" - "Ça se voit, ça se sent, le peuple est bien présent". Aos ouvidos franceses, um grito dos oprimidos e dos revolucionários latinos (LEMOINE, maio de 1998, p. 13).

Junho, 1994. Indígenas equatorianos se rebelam contra uma lei agrária, bufando alternativas possíveis ao modelo neoliberal. E camponeses bolivianos. E manifestantes mexicanos. "Está por todo lado um retrato, o de Che Guevara. Apesar do 'fim da história', são eles incuráveis 'comunistas' todos esses incríveis latinos? Ou marxistas? Marxólogos? Marxianos?" (LEMOINE, 1998, p. 13).

Quem questiona é Maurice Lemoine, que revisita:

É na Argentina, com a vinda dos imigrantes e dos refugiados políticos, notavelmente após o aniquilamento da Comuna de Paris (1871), que é implantando o ideal socialista. $O$ primeiro partido comunista latinoamericano aflora em 1918. A maior parte dos outros partidos comunistas do continente são fundados entre 1920 e 1930. Mas as grandes correntes populares que vão arar essas terras ferozmente independentes de espírito - a Aliança Popular Revolucionária Americana (APRA) no Peru, o Movimento Nacionalista Revolucionário (MNR) na Bolívia, o peronismo na Argentina - escapam a seu controle. (LEMOINE, 1998, p. 13)

Lemoine resgata a revolução vitoriosa de Fidel Castro que, diante das agressões americanas, se proclamara "oficialmente" marxista-leninista. Da ilha para a cordilheira, assinala outro "triunfo" das teses do Kremlin: o encontro de comunistas, cristãos progressistas, socialistas, sociais-democratas e radicais na Unidad Popular, que levaria pela primeira vez um marxista ao poder: Salvador Allende. Após o golpe, aliás, os golpes latino-americanos, muitos partidos comunistas migraram para a clandestinidade e a luta armada. "As lutas revolucionárias, vitoriosas ou não, logo devem pouco ao Partido Comunista. Ao contrário, as teorias de 'San Carlos' - Saint Charles (Karl Marx) como se referia maliciosamente Che Guevara na sua juventude - Ihes impregnaram, assim como animaram diversos dissidentes dos diferentes Partidos Comunistas" (LEMOINE,1998, p. 13). 
Diante do fim da URSS, do fim das guerrilhas e do minguante poder dos partidos comunistas na América Latina, que lutas restaram? Para Lemoine, muitas, sob novos matizes, novos protestos, novos partidos: lutas sociais, lutas indígenas, lutas agrárias. Símbolo de tantas lutas, antigas, novas e renovadas, estaria o "triplo signo" de Marx (na persona do subcomandante Marcos), dos zapatistas e do admirável mundo novo www, a internet. Admirador latino-americano, Lemoine costura Allende, Fidel e Zapata, Chiapas, Buenos Aires e Paris, num novelo cuja linha principal seria o pensamento marxista: "Nós podemos discordar de tal ou tal método. Mas não da própria causa. E não é 'San Carlos' que irá desmenti-los" (LEMOINE, 1998, p. 13).

Editor responsável por questões latino-americanas no Monde Diplomatique francês antes de Renaud Lambert, Maurice Lemoine se considera um escritor viajante - ou um viajante escritor. Diferentemente de seus companheiros de redação, não se graduou ou pós-graduou. Abriu, porém, o faro jornalístico a partir de suas viagens: viveu na África e num kibutz de Israel, viajou à América Latina e, de volta à França, passou a escrever. Assim, considera-se um periodista de terreno.

Na década de 1980, Lemoine passou a colaborar com Le Monde Diplomatique, “uma mescla de jornalistas de campo e de intelectuais". Lemoine diz claramente se identificar com a linha do Monde Diplomatique, como leitor e como jornalista. Uma revista de esquerda, expressão do ex-editor:

Na realidade, os jornais e os jornalistas dizem: "Estamos produzindo informação". Nunca vão dizer: "Somos de direita". Nunca vão dizê-lo ou aceitá-lo. Bom, assim é visto Le Monde Diplomatique como um misto de ilusórios arcaicos de esquerda dos anos não sei quantos de Karl Marx. Na verdade, não é assim. Le Monde Diplomatique é um jornal muito razoável. Não está nem no delírio nem no extremismo, mas... Tem uns, como dizer, pilares. ${ }^{23}$

Por pilares, Lemoine pretende destacar uma visão política, social e humana do mundo. Se questionado o que é a esquerda contemporânea, o ex-editor responde: “Na França? Bom, nós no Monde Diplomatique consideramos que, atualmente, a esquerda

\footnotetext{
${ }^{23}$ Maurice Lemoine em entrevista concedida à autora, no dia 27 de novembro de 2014.
} 
está na América Latina. Com seus defeitos e seus erros, mas, sim, a esquerda está por lá". Para Lemoine, a França atual passa pelo que passou a América Latina na década de 1990, desesperançosa e encurralada. No retrovisor do jornalista, após o levante zapatista de 1994, viriam à baila líderes não tão “clássicos”: Lula, ex-sindicalista; Chávez, ex-militar; Evo, cocalero; Mujica, ex-guerrilheiro.

Lemoine lembra que por muito tempo não gostou da ideia de líderes - por defender, como a esquerda francesa, justifica, que era preciso protagonismo do povo. Viria a mudar de ideia, ao considerar imperativa uma voz de liderança, para cristalizar as ideias, levá-las e teorizá-las. À importância dos líderes, acrescenta outro fator: o papel da mídia. Se, como pensa, os jornalistas devem ser os observadores do presente, devem ainda recordar páginas do passado para compreender os rumos políticos. Assim, os holofotes no Leste Europeu e na União Soviética teriam eclipsado a América Latina no panorama midiático, principalmente após o fim das ditaduras militares. "A América Latina desapareceu. E reapareceu com Chávez, Lula, Kirchner e tudo isso”, opina.

A fim de compreender a complexidade da dimensão latino-americana e seus desdobramentos dentro do Monde Diplomatique, vale destacar a posição de Maurice Lemoine a respeito de determinadas questões.

Primeiro, Cuba: o editor considera a transição imprescindível, mas difícil, devido às pressões norte-americanas na ilha, onde tentariam entrar como um cavalo de Troia. Lemoine defende Cuba ativamente, apesar de dizer que o regime não corresponde ao que se espera da esquerda. No nosso encontro na manhã de 27 de novembro de 2014, num café ao pé da Basílica de Sacré Coeur, $18^{\circ}$ arrondissement, lembrei o argumento da politóloga francesa Janette Habel, referindo-se aos jovens cubanos que não viveram a revolução e que não compreendem a restrição de certas liberdades individuais - e Lemoine interrompeu:

Sorrio, pois Janette Habel é uma amiga, mas há dez anos escreve o mesmo artigo: para onde vai Cuba? [risos]. O que ela diz é certo. Certamente os jovens não podem entender, mas... [...] Certamente os jovens cubanos têm dificuldade para entender o que está acontecendo, pois apesar do que ouvem lá dentro, ouvem muito lá de fora. Isso é interessante. Paris, por exemplo. Posso dar duas imagens sobre a cidade. 
Ou vamos nesse café simpático e tal [ao lado da Basílica de Sacré-Couer], e assim é Paris, uma cidade linda. Ou vamos ao lado onde eu vivo, um bairro de merda, e assim é Paris. Então, para os jovens cubanos, há uma imagem [sobre o mundo] de fora: "Oh, é uma maravilha!" Mas quando vão descobrem uma visão diferente $[\ldots . .]^{24}$

Segundo, Venezuela: o editor valoriza as conquistas chavistas, com os programas sociais e as missões. Lemoine defende o regime, a seu ver alvejado por críticas midiáticas, por ponderar um impasse: se a imprensa internacional mira críticas, muitas injustas, à Venezuela, é preciso escolher um lado da trincheira. Num jogo midiático desequilibrado, o jornalista não confia na possibilidade de defender os méritos do regime e, ao mesmo tempo, criticar o que deve ser criticado, o que daria artilharia aos inimigos. Para Lemoine, criticar o que deve ser criticado seria cair na "armadilha". ${ }^{25}$

Entre tantos intelectuais e jornalistas, Maurice Lemoine foi o único a claramente demarcar a discussão interna do Monde Diplomatique a respeito de tais questões. Além das amigáveis linhas paralelas entre diferentes opiniões a respeito de outras questões, é possível identificar uma linha divisória clara a respeito de Cuba e Venezuela:

No Monde Diplomatique há duas correntes. Pertenço a uma, a de Ignacio Ramonet e Bernard Cassen. Estamos na briga. Não somos militantes. Somos capazes de fazer críticas, mas estamos na briga [destaca punhos cerrados]. Outra corrente pretende ouvir e observar desde cima, mas não se envolver demais. No Monde Diplomatique há duas visões. A de Claude Julien estava envolvida com o terceiro-mundismo. A de Ignacio Ramonet, Bernard Cassen e eu, está envolvida na briga contra o capitalismo - ou o neoliberalismo, como dizemos, talvez para não soar marxista e blábláblá. Mas, no fim, é contra o capitalismo. Estamos na briga. Então se atacam a Chávez, vamos defendê-lo. Se atacam a Evo, vamos defendê-lo. Mas também com boas razões: nessa parte do mundo saíram milhões da pobreza. Enquanto nesse lado do mundo, cada vez temos mais pobreza. Por que vou me envergonhar de defender governos, onde sei que há erros, mas que conquistaram isso? O mecanismo da mídia é muito interessante. De 2002 a 2012, o Brasil era o "exemplo" - não tinha nenhuma crítica ao Brasil, fora Le Monde Diplomatique, que dera apoio crítico ao país. Para Le Monde e Libération etc., não tinha crítica ao Brasil, pois tinham inventado uma boa esquerda e uma má esquerda. No lado mau estava Chávez; no lado bom, Lula. De repente sumiu Chávez - e

\footnotetext{
${ }^{24}$ Maurice Lemoine em entrevista concedida à autora, no dia 27 de novembro de 2014 .

${ }^{25}$ Maurice Lemoine em entrevista concedida à autora, no dia 27 de novembro de 2014.
} 
vieram as críticas ao Brasil. Portanto, na realidade, não há um maestro da orquestra. Por que disse apoio crítico ao Brasil? Pois certamente a política interna, a reforma agrária e tudo o mais, foi decepcionante para muitos. Entretanto, na dinâmica regional, o Brasil é muito importante. E a política de Lula certamente é diferente da política de Cardoso e de Collor. Não dá para tirar tudo. É como o apoio de João Stédile. Estamos decepcionados, mas não vamos dizer: "Viva a direita!" [risos]. ${ }^{26}$

Se há duas visões dentro do Monde Diplomatique, vale identificá-las. De um lado, poderíamos destacar Maurice Lemoine, Ignacio Ramonet e Bernard Cassen, que estariam “na briga”. De outro, poderíamos indicar certamente Dominique Vidal, talvez Renaud Lambert e Serge Halimi.

Para Nicolas Harvey, a cobertura de Cuba e de Venezuela, esta última como experiência do neobolivarianismo na América Latina, constitui uma major clivagem editorial no Monde Diplomatique. De um lado, o historiador polarizaria os republicanos de esquerda (Bernard Cassen, Ignacio Ramonet, Maurice Lemoine), mais favoráveis à defesa dos regimes de Cuba e de Venezuela. De outro, os antigos comunistas (Dominique Vidal, Alain Gresh), mais declaradamente críticos ao matiz autoritário de tais regimes, em prol da defesa das liberdades individuais (HARVEY, 2011, p. 192).

"Le Monde Diplomatique é um organismo humano, com suas brigas humanas, brigas políticas", meditou Lemoine. Apesar de vibrantes, as discussões travadas na redação francesa de Le Monde Diplomatique não provocaram graves tremores fora do QG parisiense na Avenue Stephen-Pichon. Entretanto, no QG portenho, na Calle Paraguay, os desencontros pesaram mais que os encontros, culminando na saída de Gabetta.

\section{*}

Buenos Aires, 30 de agosto de 2014. Desembarco no aeroporto internacional de Ezeiza por volta das 23 horas. Literalmente aliciada por taxistas, entro num possante azulado, com destino a um hotel no moderno Puerto Madero. No caminho, diversos flashes flagrantes do país "mafioso" que tanto martelara Carlos Gabetta nos seus editoriais e no seu livro: pesos falsos, puticlubes e ocupações irregulares. Aliás, a máfia do

\footnotetext{
${ }^{26}$ Maurice Lemoine em entrevista concedida à autora, no dia 27 de novembro de 2014 .
} 
táxi não é imaginária: nessa noite tive 600 pesos furtados num golpe do motorista malandro, um senhor simpático branco e grisalho, na casa dos 60.

Paris, 28 de novembro de 2014. Espero no metrô Château-Rouge, $18^{\circ}$ arrondissement, às 13 horas. Por dentro, uma algazarra colossal de passageiros, corrompendo catracas sem timidez - famílias inteiras, idosos e jovens, entre esfarrapados e engomados. Por fora, ofertas de documentos (falsos) aos passantes. Ali encontro Maurice Lemoine, que define o metrô como fronteira entre a turística basílica de SacréCoeur e o esquecido bairro de Château-Rouge, onde predominam imigrantes africanos. Assim, Lemoine diz duas imagens possíveis da cidade-luz - uma da basílica, outra de seu barrio de mierda. ${ }^{27}$

Narro tais episódios para ilustrar as imagens refletidas cá e lá: como Carlos Gabetta vê Buenos Aires; como Maurice Lemoine vê Paris. Um, desiludido com os rumos argentinos, admirador da cultura francesa e dos ideias republicanos. Outro, desiludido com a esquerda europeia, aficionado da cultura latino-americana e suas possibilidades revolucionárias. Assim, vale destacar como tais imagens podem colidir e explodir, justapor-se e opor-se - e como é preciso, pois, olhar-se no espelho do outro.

Páginas atrás, citei as continuidades editoriais de Le Monde Diplomatique, nos seus posicionamentos sobre questões econômicas, políticas e midiáticas - um acorde original, sintonizado no tempo presente, afinado nas inquietações de seus intelectuais contra a virtuose de duas notas só: o neoliberalismo e o imperialismo. Se agora se pretende enfatizar rupturas, é preciso ouvir as vozes dissonantes dentro do Monde Diplomatique muito além de intrigas de seus intelectuais. Evidenciar os encontros e os desencontros desses jornalistas e intelectuais permite fotografar uma movimentação de ideias interessante, que por sua vez permite compreender impasses do próprio tempo presente.

Se os encontros - isto é, as críticas ao neoliberalismo e ao imperialismo suscitaram olhares otimistas a uma América Latina rebelde, que se reerguia após as ditaduras e transições democráticas, que se erguia contra o "pensamento único"

\footnotetext{
${ }^{27}$ Maurice Lemoine em entrevista concedida à autora, no dia 27 de novembro de 2014 .
} 
neoliberal e o império americano, ao mesmo tempo essa América Latina rebelde, uma vez observada por prismas diferentes, evidencia desencontros entre os intelectuais do Monde Diplomatique.

Anne-Cécile Robert ali vê um "laboratório da liberdade”, em contraposição a uma Europa congelada. Bernard Cassen nota o eco de um “"não' revolucionário”, em resposta a quem lamentava ou festejava a ausência de alternativas. Renaud Lambert radiografa uma "zona rica de esperança" para uma esquerda europeia, francamente francesa, que esquecera seus ideais.

Vale um parágrafo, porém: apesar de darem breves lembretes de que é preciso considerar os contextos diferentes dos países latino-americanos, as singularidades de suas situações políticas atuais e suas histórias, muitas vezes certos intelectuais deslizam num discurso homogeinizador da América Latina, como se fosse um continente harmônico e harmonizado. Assim, é arriscado depositar esperanças fervorosas na geopolítica latino-americana, com condições de temperatura e de pressão muito diferentes a cada país.

A Argentina é um bom exemplo para compreender a complexidade da excitação enérgica de muitos intelectuais pela América Latina. Situar Néstor Kirchner no mesmo barco que Hugo Chávez ou Evo Morales é esquecer um leme primordial que marcou a memória do país: Juan Domingo Perón. Assim, é muito delicado situar o kirchnerismo no giro a la izquerda latino-americano. E, dentro do Monde Diplomatique, é preciso lembrar dois pontos: entre os argentinos, apesar de elogiar o governo de Néstor Kirchner como "honesto" diante das circunstâncias e de endossar a primeira campanha de Cristina Fernández, Carlos Gabetta escreveu diversas críticas aos kirchnerismo, principalmente nos seus últimos meses à frente d'El Dipló; entre os franceses, Renaud Lambert declarou que, paradoxalmente, a edição europeia tende a deixar de lado a Argentina, voltando-se à edição argentina para tratar desse país tão específico. ${ }^{28}$

Cuba e Venezuela simbolizam outros desencontros entre os intelectuais. As discussões sobre o destino incerto da ilha pós-Fidel Castro, ou sobre o próprio Fidel

\footnotetext{
${ }^{28}$ Renaud Lambert em entrevista concedida à autora, no dia 2 de outubro de 2014.
} 

mas festeja as conquistas do regime da ilha caribenha, que precisa mudar, mas que já teria mudado "muito" - se o diabo está no detalhe, a diferença está no tom.

Quanto à Venezuela e ao próprio Hugo Chávez, o tom também foi diferente entre Gabetta e Ramonet - a quem destaco, entre outros autores, pois eram à época diretores das edições argentina e francesa, respectivamente. Em nenhum momento, Gabetta versa críticas a Chávez a la direita, isto é, acusando-o alucinadamente - entretanto, faz críticas muito pontuais, como a aliança com o Irã. Em nenhum momento, por sua vez, Ramonet versa críticas a Chávez - ponto.

A provocativa crítica de Dominique Vidal de uma "adoração de ídolos" latinoamericanos por intelectuais franceses ${ }^{29}$ pode ser discutível, mas está longe de ser um delírio. Não é nulo quando Bernard Cassen diz: "Se tivemos dois líderes no século XX foram Chávez e Fidel”. ${ }^{30}$ Ou quando Ramonet, autor de Fidel Castro: biografía a dos voces (2006) e Hugo Chávez: mi primera vida (2013), se “despede” dos dois líderes: em março de 2008, na renúncia de Fidel, lembrando-o como um combatente, com trajetória única, liderança e imensa influência, uma mescla de idealismo e de pragmatismo - "não é nem o monstro que descrevem algumas mídias ocidentais, nem o Superman que apresentam às vezes as mídias cubanas" (RAMONET, 2008); e em março de 2013, na morte de Chávez, rememorando o itinerário do revolucionário, que estaria ao lado de Che Guevara, Emiliano Zapata e Salvador Allende no "imaginário dos humildes da América Latina" (RAMONET, 2013, p. 22-23). Ou quando Ramonet, enquanto editor do Monde Diplomatique, refuta críticas relacionadas a agressões a direitos humanos nos governos dos dois comandantes: o informe da Anistia Internacional, que indicaria 13 presos políticos em Cuba (RAMONET, 2002, p. 18); e organizações de direitos humanos “enroladas” na campanha de difamação midiática da Venezuela (RAMONET,2007, p. 48).

\footnotetext{
${ }^{29}$ Dominique Vidal em entrevista concedida à autora, no dia 6 de outubro de 2014 .

30 Bernard Cassen em entrevista concedida à autora, no dia 10 de novembro de 2014.
} 
Entretanto, a perspectiva de Maurice Lemoine tampouco é diminuta para compreender tais posições de Cassen e Ramonet. Lemoine admite que, principalmente em casos-chave como Cuba e Venezuela, certos jornalistas de Le Monde Diplomatique se veem compelidos a escolher um lado. Se é certo dizer que, apesar das sensibilidades e afinidades diferentes, os jornalistas do Monde Diplomatique estão à esquerda, também é certo dizer que uns preferem entrar "na briga", "na luta”, outros não. Para Lemoine, diante de uma batalha midiática díspar, dominada pela mídia mainstream mais favorável à direita, uma revista como Le Monde Diplomatique não poderia ficar no muro, ao mesmo tempo defendendo os pontos positivos e criticando os pontos negativos de governos como os de Fidel Castro e de Hugo Chávez. Admitir as críticas, mesmo minimamente, significaria cair na "armadilha”. ${ }^{31}$

Maurice Lemoine, entretanto, pondera que jornalistas como Ignacio Ramonet e Bernard Cassen não são considerados “militantes”, de tal sorte que poderiam, sim, lançar críticas a tais governos: se quisessem, mas não querem, pois a briga é maior. Mirando a bigger picture, valeria abrir mão de determinadas críticas em prol da luta contra o capitalismo. Valeria, assim, defender "líderes", na palavra de Lemoine, como Chávez, Correa, Evo, Fidel, Kirchner, sem os quais esse novo momento latino-americano não existiria. Ao lado da voz popular, Lemoine valoriza assim a importância de vozes de liderança, como destacara, a fim de cristalizar as ideias, levá-las e teorizá-las. ${ }^{32}$ Vozes que, para o ex-editor, encontrariam ressonância no território latino-americano, mas seriam inaudíveis atualmente na esquerda francesa.

Ao lado dos “ídolos”, na expressão de Vidal, Gabetta miraria suas críticas a outro léxico: "populistas". E, nessa tônica, não estaria disposto a endossar o kirchnerismo, o “populismo" indígena boliviano e o "populismo" revolucionário venezuelano (GABETTA, 2006, p. 3).

Ao longo de seus editoriais foram diversas referências do argentino Gabetta à cultura e aos ideais franceses: a ideia de república, a politização e, para abreviar, liberté, égalité, fraternité, por fin (GABETTA, 2003, p. 2-3). Ao mesmo tempo, autores europeus

\footnotetext{
${ }^{31}$ Maurice Lemoine em entrevista concedida à autora, no dia 27 de novembro de 2014.

${ }^{32}$ Maurice Lemoine em entrevista concedida à autora, no dia 27 de novembro de 2014 .
} 
Vale, neste momento, um apontamento teórico. Ao longo destas páginas, fiz referência a documentos impressos de Le Monde Diplomatique, entre editoriais e artigos que marcam posicionamentos do magazine a respeito da política. Citei ainda depoimentos dos intelectuais e jornalistas de Le Monde Diplomatique, depoimentos que mesclam memórias pessoais e opiniões políticas, lembranças importantes para uns e experiências singulares para outros. Vale, portanto, lembrar que a memória, como diz Maurice Halbwachs, se constrói a partir da rememoração, assim não se pode esperar ingenuamente por relatos fidedignos ou imparciais, pois o relato corresponde à recomposição de acontecimentos vividos por uma subjetividade, o que implica uma perspectiva e uma interpretação (HALBWACHS, 2006). Memórias pessoais, sim, mas que, numa perspectiva de grande angular, compõem uma memória coletiva e revelam nuances entre os intelectuais e jornalistas de Le Monde Diplomatique. Assim, os depoimentos compõem uma fonte especial, um instrumento importante para possibilitar uma melhor compreensão das estratégias de ação e das representações nesse segmento da sociedade (FERREIRA, 2002).

Destaco três ilustrações de tais nuances que só foram reveladas a partir das oralidades, isto é, das vozes de tais intelectuais. Primeiro ponto, a posição como outsiders ou não: os sêniors Dominique Vidal e Maurice Lemoine, após décadas no Monde Diplomatique francês, se mostraram muito mais francos nas entrevistas. Já aposentados e afastados da redação, os jornalistas, de visões políticas distintas, discutiram diversas questões abertamente - ou, na expressão de Vidal, sem langue de bois [conversa fiada].

Entre os jornalistas mais jovens agora presentes na redação, como Anne-Cécile Robert e Renaud Lambert, as entrevistas foram indubitavelmente interessantes, mas mais cautelosas ao não explorar muito os conflitos internos da revista. Também fica evidente o fator estar "dentro" do Monde Diplomatique nas entrevistas com Carlos Gabetta e Carlos Alfieri. Gabetta, demitido, revirou a trajetória d’El Dipló, para, enfim, lamentar um dia desaparecer "do Le Monde Diplomatique, como se nunca tivesse 

tensões delatadas pelo antigo companheiro. 34 Por fim, estar "dentro" implica uma posição mais vigilante e com palavras mais meticulosas na hora de discutir Le Monde Diplomatique - o que fica mais nítido com os diretores novos, Serge Halimi na França e José Natanson, até agora não citado, na Argentina. Halimi, breve, mas gentil. Natanson, lacônico e ríspido.

Segundo ponto, é interessante observar como todos os intelectuais e jornalistas ouvidos nesta tese, apesar das diferentes simpatias políticas, dos distintos interesses e dos diversos repertórios, concordam num ponto: identificam-se com a história e a linha editorial de Le Monde Diplomatique - e não ocultam a admiração pelo prestigiado periódico, primeiro como leitores e depois como jornalistas. É possível, assim, compreender como a admiração e o sentimento de pertencer ao selo Le Monde Diplomatique permitem abrigar posições por vezes radicalmente diferentes de seus intelectuais, todos à esquerda.

Terceiro ponto, portanto, o posicionamento à esquerda pode ser lido nas páginas da revista, mas só os depoimentos de seus intelectuais permitiram descobrir e evidenciar os detalhes sobre tal posicionamento e, assim, enriquecer e entrelaçar a discussão sobre o papel dos intelectuais, o papel dos jornalistas e as esquerdas contemporâneas, na França e na América Latina.

\section{Considerações finais}

Dedicarei estas últimas linhas a uma breve síntese. Nas relações entre França e América Latina, por um lado, intelectuais latino-americanos dedicariam, como dedicaram noutros momentos históricos, prestígio à intelectualidade francesa - o que se concretizaria com Le Monde Diplomatique, uma revista francesa "importada” na América

\footnotetext{
33 Carlos Gabetta em entrevista concedida à autora, no dia 11 de setembro de 2012.

${ }^{34}$ Carlos Alfieri em entrevista concedida à autora, no dia $1^{\circ}$ de setembro de 2014.
} 
Latina. Por outro lado, intelectuais europeus também dedicariam certo fascínio sobre a realidade latino-americana, diante da ascensão de novos governos “progressistas”. Esses espelhos, coloridos e fragmentados, mas não oxidados, revelam, no fundo, uma incógnita ainda maior: entre ideias e ilusões, o que é ser de esquerda no século XXI.

Entre palavras e páginas, os intelectuais de Le Monde Diplomatique defendem ideais como a justiça e a liberdade e defendem a democracia como palco para tal prélio isto é, os fins e os meios. Mas é preciso matizar a questão sobre onde está a esquerda. Ou sobre como argentinos e franceses se entreolham num jogo político de espelhos. No extremo argentino, Carlos Gabetta não camufla a admiração diante dos ideais republicanos prometidos da Revolução Francesa. No polo francês, Maurice Lemoine, tampouco oculta o fascínio diante das promissoras iniciativas "rebeldes" da América Latina. Se Gabetta mira o passado francês, Lemoine miraria o futuro latino-americano? A almejada esquerda estaria “idealizada” apenas no outro?

Arrisquei, nestas páginas, demonstrar como uma revista de linha editorial demarcada (e famosa) à esquerda, com críticas severas aos rumos do mundo atual nos lemes do neoliberalismo e do imperialismo, também tem suas contradições e discordâncias. Encravado na história do tempo presente, Le Monde Diplomatique evidencia como uma revista é um organismo vivo, feito de sociabilidades, amizades e animosidades intelectuais.

Nas páginas de Le Monde Diplomatique e nas vozes de seus principais intelectuais, por fim, a esquerda agora se inquietaria para afastar os fantasmas soviéticos das desilusões comunistas do século XX na Europa, reiterando a necessidade de ascender ao poder por vias democráticas, donde apostaria nas ideias do século XXI simbolizadas por vitórias impressionantes nas urnas na América Latina. Vozes dissonantes, certamente, mas minimamente afinadas na clave de Le Monde Diplomatique. 


\section{Referências}

AGUIRRE, Carlos (Org.). Militantes, intelectuales y revolucionários: ensayos sobre marxismo e izquierda en América Latina. Raleigh: Editorial A Contracorriente, 2009.

ALBERTI, Verena. Manual de história oral. Rio de Janeiro: Editora FGV, 2004.

CALCAGNO, Alfredo; CALCAGNO, Eric. “Alternativas al neoliberalismo”. Le Monde Diplomatique Edición Cono Sur, Buenos Aires, n. 13, p.6-7, julho de 2000.

FERREIRA, Marieta Moraes de. "História, tempo presente e história oral”. Topoi: Revista UFRJ. Rio de Janeiro, n. 5, vol. 3, p. 314-332, dezembro de 2002.

FREITAS, Sonia Maria de. História oral: possibilidades e procedimentos. São Paulo: Humanitas, 2006.

FUNES, Patricia. Salvar la nación: intelectuales, cultura y política en los años veinte latinoamericanos. Buenos Aires: Prometeo, 2006.

GABETTA, Carlos. "París/Buenos Aires". Le Monde Diplomatique Edición Cono Sur, Buenos Aires, n. 137, p. 2-3, novembro de 2010.

GABETTA, Carlos. "Populistas, liberales y sociedad". Le Monde Diplomatique Edición Cono Sur, Buenos Aires, n. 95, p.3, maio de 2007.

GABETTA, Carlos. “Necesidad de una modesta utopía”. Le Monde Diplomatique Edición Cono Sur, Buenos Aires, n. 60, p.3, junho de 2004.

GABETTA, Carlos. "Democracias revolucionarias". Le Monde Diplomatique Edición Cono Sur, Buenos Aires, n. 79, p. 2-3, janeiro de 2006.

GILMAN, Claudia. Entre la pluma y el fusil: debates y dilemas del escritor revolucionario en América Latina. Buenos Aires: Siglo XXI Editores, 2012.

HALBWACHS, Maurice. A memória coletiva. Traduzido por Beatriz Sidou. São Paulo: Editora Centauro, 2006.

HARVEY, Nicolas. Le Monde Diplomatique: un concept éditorial hybride au confluente du journalisme, de l'université et du militantisme., 2011,. Tese (Doutorado em Ciência Política) - Université de Rennes I, Rennes, 2011. 
LEMOINE, Maurice. "Zapata, Guevara, Allende... San Carlos”. Le Monde Diplomatique, Paris, n.530, p. 13, maio de 1998.

MEIHY, José Carlos Sebe Bom. Manual de história oral. São Paulo: Loyola, 1998.

MEIHY, José Carlos Sebe Bom; HOLANDA, Fabíola. História oral. São Paulo: Contexto, 2007.

MODONESI, Massimo. "Crisis hegemónica y movimentos antagonistas en América Latina: una lectura gramsciana del cambio de época”. In: AGUIRRE, Carlos (Org.). Militantes, intelectuales y revolucionários: ensayos sobre marxismo e izquierda en América Latina Raleigh: Editorial A Contracorriente, 2009, p. 151-177.

PRADO, Maria Ligia Coelho. "América Latina: história comparada, histórias conectadas, história transnacional”. Anuário. Rosário: Universidad Nacional de Rosário, n. 24, p. 9-22, 2013.

PRADO, Maria Ligia Coelho. "Repensando a história comparada da América Latina”. Revista de História. São Paulo: Universidade de São Paulo, n. 153, p. 11-3, dezembro de 2005.

RAMONET, Ignacio. “Anticastrismo primario”. Le Monde Diplomatique Edición Cono Sur, Buenos Aires, n. 34, p. 18-19, abril de 2002.,

RAMONET, Ignacio. "Hugo Chávez". Le Monde Diplomatique Edición Cono Sur, Buenos Aires, n. 98, p. 48, agosto de 2007.

RAMONET, Ignacio. “Itinéraire d'un révolutionnaire". Le Monde Diplomatique, Paris, n. 709, p. 22-23, abril de 2013.

RAMONET, Ignacio.. "Fidel Castro cambia de terreno, pero no de bando". Le Monde Diplomatique Edición Cono Sur, Buenos Aires, n. 105, p. 40, março de 2008.

RAMONET, Ignacio.. “Populismo francés”. Le Monde Diplomatique Edición Cono Sur, Buenos Aires, n. 96, p. 40, maio de 2007.

ROLLAND, Denis. A crise do modelo francês: a França e a América Latina: cultura, política e identidade. Brasília: Editora UnB, 2005.

SIRINELLI, Jean-François. “Os intelectuais”. In. RÉMOND, René (Org.). Por uma história política. Traduzido por Dora Rocha. Rio de Janeiro: UFRJ/FGV, 1996, p. 231-269. 
edição. Buenos Aires: Emecé, 2011.

WEINBERG, Gregorio. "El pensamiento francés en el Río de la Plata". Le Monde Diplomatique Edición Cono Sur, n.13, p.11-12, julho de 2000.

WEINSTEIN, Barbara. "Pensando a história fora da nação: a historiografia da América Latina e o viés transnacional”. Revista Eletrônica da Anphlac. São Paulo: Associação Nacional de Pesquisadores e Professores de História das Américas (Anphlac), n. 14, p. 1329, janeiro/junho de 2013. Disponível em: < http://www.revistas.fflch.usp.br/anphlac/article/view/2331> Acesso em: 18 de fevereiro de 2016. 